\title{
Survey Research and the Politics of Old Age Welfare in a Period of System Crisis
}

\author{
William R. Earnest and Irene Padavic ${ }^{1}$
}

This paper considers the effect of the ensemble of interest group liberalism (IGL) and the catch-all party on political analysis and communication, focusing on support for programs for the elderly and the problems inherent in a noted gerontologist's ideology-bound defense of them. The IGL gives rise to a "catch-all" party system whose "big tent" appeal inevitably obliges the party to downplay divisive issues. Mirroring these conflict-suppressing routines of IGL, survey research has encouraged an interest group-oriented political vocabulary that is inadequate to the current political conjuncture, which is marked by protest movements increasingly oriented to class conflict. The alternative question format we are urging would put respondents in the position of political subjects, granting them the use of political "ego functions" that are typically arrogated by the major parties. We propose survey items useful to scholars and activists seeking to develop questions assessing possible cross-generational (or other) coalitions. [Article copies available for a fee from The Transformative Studies Institute. E-mail address: journal@transformativestudies.org Website: http://www.transformativestudies.org (C2019 by The Transformative Studies Institute. All rights reserved.]

KEYWORDS: Old-Age Security, Survey Research, Interest-Group Liberalism, Cross-Generational Coalitions, AARP.

As the proportion of national wealth going to the elderly increases, the possibility of a conflict between the Baby Boom generation and younger

\footnotetext{
${ }^{1}$ William R. Earnest received a joint Ph.D. in Political Science and Psychology at the University of Michigan and is currently an independent scholar who maintains a clinical psychology practice. His published articles include "Ideology and the Role of Dialogue in Political Mobilization” in the 2014 Hand book of Social Justice and Psychology.

Irene Padavic earned her Ph.D. in Sociology at the University of Michigan and is currently the Mildred and Claude Pepper Professor of Sociology at Florida State University. Her research concerns workplace inequality, union renewal, and gender and race in organizations.
} 